\title{
METODE DECISION TREE ALGORITMA C.45 DALAM MENGKLASIFIKASI DATA PENJUALAN BISNIS GERAI MAKANAN CEPAT SAJI
}

\author{
Eka Pandu Cynthia ${ }^{1}$, Edi Ismanto ${ }^{2}$ \\ ${ }^{1}$ UIN Sultan Syarif Kasim Riau, ${ }^{2}$ Universitas Muhammadiyah Riau \\ 1Jalan HR.Soebrantas KM.15 Simpang Baru, Panam, Pekanbaru-Riau, \\ ${ }^{2}$ Jalan Tuanku Tambusai, Pekanbaru-Riau \\ 1eka.pandu.cynthia@uin-suska.ac.id, 2edi.ismanto@umri.ac.id
}

\begin{abstract}
Advances in technology and information currently produces smart innovations in business, which can be called business intelligence. One that we can use is Data Mining technology in digging useful information from sales company data warehouse. The purpose of this research is to apply data mining decision decision tree algorithm C4.5 on fast food outlets business and expected to provide information in the form of sales information about food menu that most liked by customers and less popular (bestselling and less in demand). The methodology used in classifying the sales of this research uses the steps of Algorithm C.45, The process uses five steps in KDD (Knowledge Discovery in Databases), which perpetuates activities such as pre-processing, transformation, data mining, interpretation and evaluation. In addition to performing calculations manually, this research case is also tested using Rapidminer application. From the results of the experiment to find data from the sales data of fast food outlets using algorithm C4.5 results of entropy and the highest gain is 1.501991 on the Food Menu attributes on manual calculations. When using the Rapidminer application the results of the results tree as shown in Figure 3.2. Price (s) - Sold Out - Food Menu (Bento Rice = Less Selling, Chest = Laris) Weight (weight) each attribute: Price (0.738), Menu Type (0.067), Sold Number (0.156), Sales Status (0.040).
\end{abstract}

Keywords: Bussiness Intelligence, C4.5, Clasification, Data Minig, Decision Tree.

\begin{abstract}
Abstrak
Kemajuan teknologi dan informasi pada saat ini melahirkan inovasi-inovasi cerdas dalam berbisnis, yang dapat kita sebut kecerdasan bisnis atau business intelligence. Salah satu yang dapat kita manfaatkan adalah teknologi Data Mining dalam menggali informasi yang bermanfaat dari gudang data perusahaan penjualan. Tujuan penelitian ini adalah penulis mencoba menerapkan teknik data mining metode decision tree algoritma C4.5 pada bisnis gerai makanan cepat saji dan diharapkan dapat memberikan informasi berupa klasifikasi penjualan menu makanan yang paling digemari pelanggan dan kurang digemari (laris dan kurang laris). Metodologi yang digunakan dalam mengklasifikasi penjualan menu makanan ini menggunakan tahapan Algoritma C.45, Prosesnya menggunakan lima langkah dalam KDD (Knowledge Discovery in Databases), yang mencakup beberapa aktivitas yaitu seleksi, praproses, transformasi, data mining, interprestasi dan evaluasi. Selain melakukan perhitungan secara manual, kasus penelitian ini juga diujikan menggunakan aplikasi Rapidminer. Dari hasil percobaan pencarian pohon hasil keputusan dari data penjualan gerai makanan cepat saji menggunakan algoritma C4.5 dihasilkan nilai entropy dan gain tertinggi yaitu 1,501991 pada atribut-atribut Menu Makanan pada perhitungan manual. Sedangkan menggunakan aplikasi Rapidminer diperoleh hasil pohon keputusan seperti terlihat pada Gambar 3.2. Harga - Jumlah Terjual - Menu Makanan (Rice Bento = Kurang Laris, Dada = Laris) dengan bobot (weight) masing-masing atribut: Harga (0,738), Jenis Menu (0,067), Jumlah Terjual $(0,156)$, Status Penjualan $(0,040)$.
\end{abstract}

Kata kunci: Business Intelligence, C4.5, Data Mining, Decision Tree, Klasifikasi. 


\section{PENDAHULUAN}

Makan merupakan hal mendasar yang dibutuhkan manusia dalam usaha bertahan hidup, sehingga bermunculan beragam bisnis yang menawarkan aneka jenis makanan. Namun dewasa ini kita rasakan bahwa makanan telah menjelma dari sekedar "kebutuhan bertahan hidup" menjadi "gaya hidup". Hal ini dapat kita lihat dari banyaknya gerai penjual makanan yang sebenarnya menu makanan tersebut biasa-biasa saja lalu oleh pelaku bisnis kuliner disulap menjadi makanan yang "kekinian" dan akhirnya menjadi favorit segala kalangan usia. Bahkan gaya hidup manusia zaman sekarang yang serba menginginkan kepraktisan dan cepat, melahirkan usaha makanan cepat saji atau yang sering kita sebut fast food. Kemajuan teknologi dan informasi pada saat ini melahirkan inovasi-inovasi cerdas dalam berbisnis, yang dapat kita sebut kecerdasan bisnis atau business intelligence. Salah satu yang dapat kita manfaatkan adalah teknologi Data Mining dalam menggali informasi yang bermanfaat dari gudang data perusahaan penjualan.

Pengambil keputusan berusaha untuk memanfaatkan gudang data yang sudah dimiliki untuk menggali informasi yang berguna membantu mengambil kesimpulan, hal ini menjadikan munculnya cabang ilmu baru untuk mengatasi masalah penggalian informasi atau pola yang penting atau menarik dari data dalam jumlah yang besar, yang disebut dengan data mining. Penggunaan teknik data mining diharapkan dapat memberikan pengetahuan-pengetahuan baru yang sebelumnya belum diketahui [1].

Definisi lain data mining adalah serangkaian proses yang memperkerjakan satu atau lebih teknik pembelajaran komputer untuk menganalisis dan mengekstrak pengetahuan secara otomatis atau serangkaian proses untuk menggali nilai tambah dari suatu kumpulan data berupa pengetahuan yang selama ini tidak diketahui secara manual [2][3]. Penelitian terdahulu tentang pemanfaatan data mining pada bisnis diantaranya: pengklasifikasian data nasabah bank untuk pengambilan keputusan pemberian kredit [4][5], prediksi jumlah penjualan motor [6], rekomendasi penerimaan mitra penjualan [7], informasi strategis penjualan batik [5], penjualan produk terlaris distro [8] dan klasifikasi kesetiaan pelanggan terhadap merk produk [9].

Tujuan penelitian ini adalah penulis mencoba menerapkan teknik data mining metode decision tree algoritma C4.5 pada bisnis gerai makanan cepat saji XYZ dan diharapkan dapat memberikan informasi berupa klasifikasi penjualan menu makanan yang paling digemari pelanggan dan kurang digemari (laris dan tidak laris). Sehingga kedepannya pemilik bisnis ini dapat melakukan analisa menu mengikuti trend dan kegemaran pelanggannya.

\section{METODOLOGI PENELITIAN}

Metodologi yang digunakan oleh penulis dalam mengklasifikasi penjualan menu makanan pada gerai makanan cepat saji XYZ menggunakan tahapan Algoritma C.45, Prosesnya menggunakan lima langkah dalam KDD (Knowledge Discovery in Databases), yang mencakup beberapa aktivitas yaitu seleksi, praproses, transformasi, data mining, interprestasi dan evaluasi. 


\subsection{Tahapan Metodologi Penelitian}

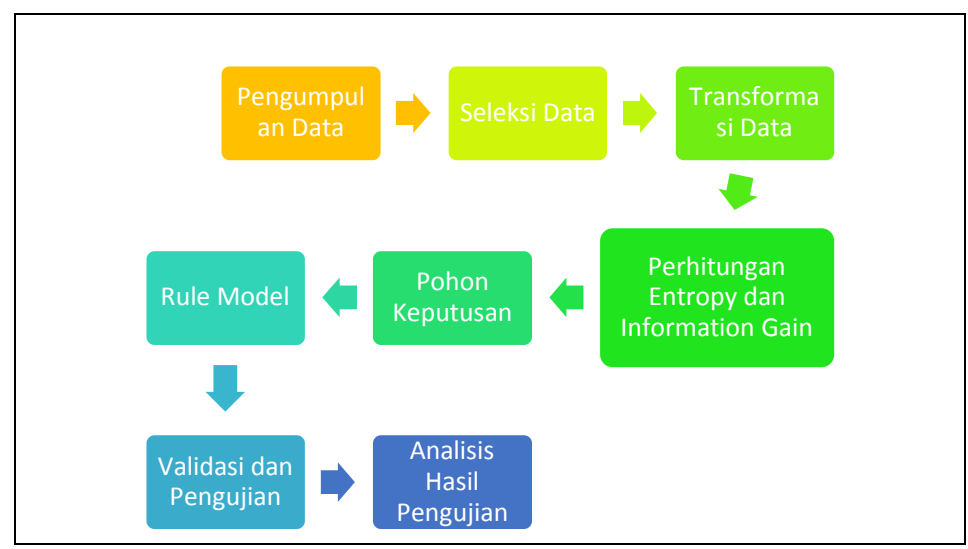

Gambar 1. Tahapan Penelitian

\section{A. Pengumpulan Data}

Pengumpulan data adalah mengumpulkan data-data yang akan digunakan dalam proses algoritma klasifikasi C4.5.

\section{B. Seleksi Data}

Seleksi data adalah memilih data yang akan digunakan dalam proses algoritma klasifikasi C4.5. Tujuan dari seleksi data adalah menciptakan himpunan data target, pemilihan himpunan data, atau memfokuskan pada subset variabel atau sampel data, dimana penemuan (discovery) akan dilakukan [1][10].

\section{Transformasi Data}

Transformasi data adalah proses mentransformasi atau mengubah data ke dalam bentuk yang sesuai, agar dapat di proses dengan perhitungan algoritma C4.5..

\section{Perhitungan Entropy dan Information Gain}

Perhitungan semua atribut/variabel, entropy menggunakan rumus (1) dan information gain menggunakan rumus (2) untuk mengetahui information gain tertinggi yang akan dijadikan simpul akar pada pembuatan pohon keputusan.

\section{E. Pohon Keputusan (Decision Tree)}

Pohon keputusan adalah hasil dari proses perhitungan entropy dan information gain, setelah perhitungan berulang-ulang sampai semua atribut pohon memiliki kelas dan tidak bisa lagi dilakukan proses perhitungan.

\section{F. Aturan-aturan/ Rule Model}

Aturan-aturan/ Rule model adalah uraian penjelasan yang merepresentasikan sebuah pohon keputusan. 


\section{G. Validasi dan Pengujian}

Validasi dan pengujian adalah Pengujian yang dilakukan untuk mengetahui semua fungsi bekerja dengan baik atau tidak. Validasi dilakukan dengan Ten-fold Cross Validation. Ten-fold Cross Validation adalah validasi yang dilakukan dengan cara membagi suatu set data menjadi sepuluh segmen yang berukuran sama besar dengan cara melakukan pengacakan data. Validasi dan pengujian dilakukan untuk mengetahui tingkat akurasi, presisi, dan recall dari hasil prediksi klasifikasi. Akurasi adalah persentase dari catatan yang diklasifikasikan dengan benar dalam pengujian dataset. Presisi adalah persentase data yang diklasifikasikan sebagai model baik yang sebenarnya juga baik. Recall adalah pengukuran tingkat pengenalan positif sebenarnya.

\section{H. Analisis Hasil Pengujian}

Analisa yang dilakukan untuk memastikan bahwa hasil pengujian benar-benar sesuai dengan pembahasan. Analisa dilakukan dengan melakukan perhitungan kembali hasil validasi dan pengujian(akurasi, presisi, dan recall) secara manual. Apakah perhitungan yang dilakukan akan menghasilkan nilai yang sama atau tidak, dibantu dengan Confusion matrix. Confusion Matrix adalah model yang akan membentuk matrix yang terdiri dari true positif atau tupel positif dan true negatif atau tupel negatif. Confusion matrix berisi informasi aktual (actual) dan prediksi (predicted) pada sisitem klasifikasi. Confusion matrix dapat memvisualisasi kinerja algoritma klasifikasi.

\subsection{Analisis Data Mining}

Data mining adalah bagian integral dari penemuan pengetahuan dalam database yang merupakan proses dengan urutan sebagai berikut [11][12] :

1. Data cleaning (untuk menghilangkan noise dan inkonsistensi data)

2. Data integration (beberapa data sources akan dikombinasikan)

3. Data selection (hanya data yang dapat dipakai untuk analisis saja yang akan diambil dari database)

4. Data transformation (data akan ditransformasikan ke bentuk yang lebih terstruktur untuk mempermudah proses data mining)

5. Data mining (proses utama data mining dimana teknik data mining diterapkan)

6. Pattern evaluation

7. Knowledge presentation (dimana visualisasi dan representasi hasil diberikan kepada pengguna)

Tujuan utama penerapan data mining adalah untuk prediksi (prediction) dan uraian (description). Klasifikasi adalah proses menemukan model (atau fungsi) yang akan mengelompokkan kelas data sehingga dapat memprediksi kelas obyek yang tidak diketahui. Modelyang diperoleh bias diwakili diberbagai bentuk, seperti klasifikasi berbentuk aturan IF-THEN, pohon keputusan, rumus matematika, atau jaringan saraf tiruan. Rule based classification adalah model berbentuk seperangkat 
aturan berbentuk IF-THEN. Aturan berbentuk IF-THEN adalah cara yang baik untuk merepresentasikan pengetahuan. Aturan dapat diekstraksi dari pohon keputusan.

\subsection{Algoritma C4.5}

Algoritma C4.5. merupakan kelompok algoritma pohon keputusan (decision tree). Algoritma ini mempunyai input berupa training samples dan samples. Training samples berupa data contoh yang akan digunakan untuk membangun sebuah tree yang telah diuji kebenaranya. Sedangkan samples merupakan field-field data yang nantinya akan kita gunakan sebagai parameter dalam melakukan klasifikasi data [7].

Algoritma C4.5 adalah salah satu metode untuk membuat decision tree berdasarkan training data yang telah disediakan. Algoritma C4.5 merupakan pengembangan dari ID3. Beberapa pengembangan yang dilakukan pada C4.5 adalah sebagai antara lain bisa mengatasi missing value, bisa mengatasi continue data, dan praining. Secara garis besar langkah-langkah yang dilakukan oleh Algoritma C.45 dalam membentuk pohon keputusan adalah sebagai berikut:

Input : sample training, label training, atribut

1. Membuat simpul akar untuk pohon yang dibuat

2. Jika semua sampel positif, berhenti dengan suatu pohon dengan satu simpul akar, beri tanda $(+)$

3. Jika semua sampel negatif, berhenti dengan suatu pohon dengan satu simpul akar, beri tanda $(-)$

4. Jika atribut kosong, berhenti dengan suatu pohon dengan suatu simpul akar, dengan label sesuai nilai yang terbanyak yang ada pada label training

5. Untuk yang lain, Mulai

a. A ---- atribut yang mengklasifikasikan sampel dengan hasil terbaik (berdasarkan gain rasio)

b. Atribut keputusan untuk simpul akar ---- A

c. Untuk setiap nilai, vi, yang mungkin untuk A

1) Tambahkan cabang di bawah akar yang berhubungan dengan $A=v i$

2) Tentukan sampel $S_{v i}$ sebagai subset dari sampel yang mempunyai nilai vi untuk atribut A

3) Jika sampel $S_{v i}$ kosong

i. Di bawah cabang tambahkan simpul daun dengan label = nilai yang terbanyak yang ada pada label training

ii. $\quad$ Yang lain tambah cabang baru di bawah cabang yang sekarang C 4.5 (sample training, label training, atribut -

d. Berhenti [A].

Output : Decision Tree.

Mengubah tree yang dihasilkan dalam beberapa rule. Jumlah rule sama dengan jumlah path yang mungkin dapat dibangun dari root sampai leaf node. Tree Praining dilakukan untuk menyederhanakan tree sehingga akurasi dapat bertambah. Pruning ada dua pendekatan, yaitu : 
1) Pre-praining, yaitu menghentian pembangunan suatu subtree lebih awal (yaitu dengan memutuskan untuk tidak lebih jauh mempartisi data training). Saat seketika berhenti, maka node berubah menjadi leaf (node akhir). Node akhir ini menjadi kelas yang paling sering muncul di antara subset sampel.

2) Post-praining, yaitu menyederhanaan tree dengan cara membuang beberapa cabang subtree setelah tree selesai dibangun. Node yang jarang dipotong akan menjadi leaf (node akhir) dengan kelas yang paling sering muncul.

Secara umum algoritma C4.5 adalah untuk membangun pohon keputusan adalah sebagai berikut :

1. Pilih atribut sebagai akar

2. Buat cabang untuk masing-masing nilai

3. Bagi kasus dalam cabang

4. Ulangi proses untuk masing-masing cabang sampai semua kasus pada cabang memiliki kelas yang sama.

\subsection{Entropy dan Information Gain}

Sebuah obyek yang diklasifikasikan dalam pohon harus dites nilai Entropy nya. Entropy adalah ukuran dari teori informasi yang dapat mengetahui karakteristik dari impuryt dan homogenity dari kumpulan data. Dari nilai Entropy tersebut kemudian dihitung nilai information gain (IG) masing-masing atribut. Entropy (S) merupakan jumlah bit yang diperkirakan dibutuhkan untuk dapat mengekstrak suatu kelas (+ atau -) dari sejumlah data acak pada ruang sampel S. Entropy dapat dikatakan sebagai kebutuhan bit untuk menyatakan suatu kelas [8]. Semakin kecil nilai Entropy maka akan semakin Entropy digunakan dalam mengekstrak suatu kelas. Entropy digunakan untuk mengukur ketidakaslian S.sistem informasi atau disebut dengan processing system.

Pemilihan atribut sebagai simpul, baik akar maupun simpul internal didasarkan pada nilai Gain tertinggi dari atribut-atribut yang ada. Rumus menghitung nilai entropy mengunakan Persamaan 1 [3] :

$$
\operatorname{Entropy}(S)=\sum_{i=1}^{n}-p i \log _{2}
$$

Keterangan dari Persamaan 1 :

S : himpunan kasus.

$\mathrm{n}$ : jumlah partisi $\mathrm{S}$

Pi : proporsi Si terhadap S

Information gain adalah salah satu attribute selection measure yang digunakan untuk memilih test attribute tiap node pada tree. Atribut dengan informasi gain tertinggi dipilih sebagai test atribut dari suatu node. Gain (S,A) merupakan perolehan informasi dari atribut A relative terhadap output data $\mathrm{S}$. Perolehan informasi didapat dari output data atau variable dependent $\mathrm{S}$ yang dikelompokkan berdasarkan atribut $A$, dinotasikan dengan gain $(S, A)$. Menghitung nilai information gain menggunakan Persamaan 2 : 
Jurnal Riset Sistem Informasi Dan Teknik Informatika (JURASIK)

Volume (3) Juli 2018, pp 1-13

ISSN: 2527-5771/EISSN: 2549-7839

http://tunasbangsa.ac.id/ejurnal/index.php/jurasik

$$
\operatorname{Gain}(S, A)=\operatorname{entropy}(S)-\sum_{i=1}^{n} \frac{\left|S_{i}\right|}{|S|} * \operatorname{entropy}\left(S_{i}\right)
$$

\section{Keterangan dari Persamaan 2 :}

$\mathrm{S} \quad$ : himpunan kasus.

A : Atribut.

n : jumlah partisi atribut A.

$\left|\mathrm{S}_{\mathrm{i}}\right| \quad$ : jumlah kasus pada partisi ke i.

$|\mathrm{S}|$ : jumlah kasus dalam S.

\section{HASIL DAN PEMBAHASAN}

\subsection{Analisa Data}

Data yang digunakan adalah contoh data penjualan pada sebuah gerai makanan cepat saji dalam satu bulan (30 hari).

Tabel 1. Data Penjualan

\begin{tabular}{|c|c|c|c|c|c|c|c|}
\hline No. & $\begin{array}{c}\text { Tanggal } \\
\text { Penjualan }\end{array}$ & $\begin{array}{l}\text { Kode } \\
\text { Menu }\end{array}$ & Jenis Menu & Nama Menu & Harga & $\begin{array}{l}\text { Jumlah } \\
\text { Terjual }\end{array}$ & $\begin{array}{c}\text { Status } \\
\text { Penjualan }\end{array}$ \\
\hline 1 & \multirow{23}{*}{ 1-Jun-2018 } & SM01 & Makanan & Super Mumer & 20000 & 15 & Laris \\
\hline 2 & & PM01 & Makanan & Paket Mumer 1 & 16000 & 10 & Kurang Laris \\
\hline 3 & & PM02 & Makanan & Paket Mumer 2 & 19000 & 13 & Laris \\
\hline 4 & & PM03 & Makanan & Paket Mumer 3 & 23000 & 12 & Kurang Laris \\
\hline 5 & & PM04 & Makanan & Paket Mumer 4 & 27000 & 10 & Kurang Laris \\
\hline 6 & & RB01 & Makanan & Rice Bento & 10000 & 15 & Kurang Laris \\
\hline 7 & & OB01 & Makanan & Original Burger & 8000 & 15 & Kurang Laris \\
\hline 8 & & AG01 & Makanan & Ayam Geprek & 15000 & 17 & Laris \\
\hline 9 & & FF01 & Makanan & French Fries & 8000 & 10 & Kurang Laris \\
\hline 10 & & DD01 & Makanan & Dada & 10000 & 25 & Kurang Laris \\
\hline 11 & & PA01 & Makanan & Paha Atas & 9000 & 15 & Kurang Laris \\
\hline 12 & & SY01 & Makanan & Sayap & 8000 & 19 & Kurang Laris \\
\hline 13 & & PB01 & Makanan & Paha Bawah & 8000 & 16 & Kurang Laris \\
\hline 14 & & NP01 & Makanan & Nasi Putih & 4000 & 45 & Laris \\
\hline 15 & & IF01 & Minuman & Ice Float Mocca & 7000 & 7 & Kurang Laris \\
\hline 16 & & IF02 & Minuman & Ice Float Tropical & 7000 & 9 & Kurang Laris \\
\hline 17 & & IF03 & Minuman & Ice Float Lechy & 7000 & 11 & Kurang Laris \\
\hline 18 & & IF04 & Minuman & Ice Float Orange & 7000 & 15 & Kurang Laris \\
\hline 19 & & IF05 & Minuman & Ice Float Mango & 7000 & 13 & Kurang Laris \\
\hline 20 & & SIC01 & Minuman & Sundae Ice Cream & 5000 & 25 & Laris \\
\hline 21 & & SD01 & Minuman & Pepsi & 5000 & 35 & Kurang Laris \\
\hline 22 & & SD02 & Minuman & Mirinda & 5000 & 29 & Laris \\
\hline 23 & & AM01 & Minuman & Air Mineral & 4000 & 35 & Kurang Laris \\
\hline$\vdots$ & $\bar{\vdots}$ & $\vdots$ & $\bar{\vdots}$ & $\vdots$ & $\bar{\vdots}$ & $\bar{\vdots}$ & $\bar{\vdots}$ \\
\hline 668 & \multirow{8}{*}{ 30-Jun-2018 } & SM01 & Makanan & Super Mumer & 20000 & 24 & Kurang Laris \\
\hline 669 & & PM01 & Makanan & Paket Mumer 1 & 16000 & 17 & Laris \\
\hline 670 & & PM02 & Makanan & Paket Mumer 2 & 19000 & 9 & Kurang Laris \\
\hline 671 & & PM03 & Makanan & Paket Mumer 3 & 23000 & 11 & Laris \\
\hline 672 & & PM04 & Makanan & Paket Mumer 4 & 27000 & 29 & Kurang Laris \\
\hline 673 & & RB01 & Makanan & Rice Bento & 10000 & 17 & Kurang Laris \\
\hline 674 & & OB01 & Makanan & Original Burger & 8000 & 27 & Kurang Laris \\
\hline 675 & & AG01 & Makanan & Ayam Geprek & 15000 & 30 & Laris \\
\hline
\end{tabular}

Mengklasifikasi Data Penjualan Bisnis Gerai Makanan Cepat Saji (Eka Pandu Cynthia)| 7 
Jurnal Riset Sistem Informasi Dan Teknik Informatika (JURASIK)

Volume (3) Juli 2018, pp 1-13

ISSN: 2527-5771/EISSN: 2549-7839

http://tunasbangsa.ac.id/ejurnal/index.php/jurasik

\begin{tabular}{|c|c|c|c|c|c|c|c|}
\hline No. & $\begin{array}{c}\text { Tanggal } \\
\text { Penjualan }\end{array}$ & $\begin{array}{l}\text { Kode } \\
\text { Menu }\end{array}$ & Jenis Menu & Nama Menu & Harga & $\begin{array}{l}\text { Jumlah } \\
\text { Terjual }\end{array}$ & $\begin{array}{c}\text { Status } \\
\text { Penjualan } \\
\end{array}$ \\
\hline 676 & & FF01 & Makanan & French Fries & 8000 & 10 & Kurang Laris \\
\hline 677 & & DD01 & Makanan & Dada & 10000 & 29 & Laris \\
\hline 678 & & PA01 & Makanan & Paha Atas & 9000 & 29 & Kurang Laris \\
\hline 679 & & SY01 & Makanan & Sayap & 8000 & 17 & Laris \\
\hline 680 & & PB01 & Makanan & Paha Bawah & 8000 & 10 & Laris \\
\hline 681 & & NP01 & Makanan & Nasi Putih & 4000 & 33 & Kurang Laris \\
\hline 682 & & IF01 & Minuman & Ice Float Mocca & 7000 & 7 & Kurang Laris \\
\hline 683 & & IF02 & Minuman & Ice Float Tropical & 7000 & 8 & Laris \\
\hline 684 & & IF03 & Minuman & Ice Float Lechy & 7000 & 7 & Kurang Laris \\
\hline 685 & & IF04 & Minuman & Ice Float Orange & 7000 & 10 & Kurang Laris \\
\hline 686 & & IF05 & Minuman & Ice Float Mango & 7000 & 13 & Laris \\
\hline 687 & & SIC01 & Minuman & Sundae Ice Cream & 5000 & 33 & Kurang Laris \\
\hline 688 & & SD01 & Minuman & Pepsi & 5000 & 22 & Laris \\
\hline 689 & & SD02 & Minuman & Mirinda & 5000 & 25 & Kurang Laris \\
\hline 690 & & AM01 & Minuman & Air Mineral & 4000 & 30 & Laris \\
\hline
\end{tabular}

Data penjualan tersebut lalu diklasifikasikan menjadi 5 bagian, yaitu pembagian berdasarkan Jenis Menu, Menu Makanan, Menu Minuman, Harga dan Jumlah Terjual.

Tabel 2. Klasifikasi Berdasarkan Jenis Menu

\begin{tabular}{|c|c|c|}
\hline \multirow{2}{*}{$\begin{array}{c}\text { JENIS } \\
\text { MENU }\end{array}$} & \multicolumn{2}{|c|}{ STATUS PENJUALAN } \\
\cline { 2 - 3 } & LARIS & $\begin{array}{c}\text { KURANG } \\
\text { LARIS }\end{array}$ \\
\hline Makanan & 165 & 255 \\
\hline Minuman & 111 & 159 \\
\hline
\end{tabular}

Tabel 3. Klasifikasi Berdasarkan Menu Minuman

\begin{tabular}{|l|c|c|}
\hline \multirow{2}{*}{ Menu Minuman } & \multicolumn{2}{|c|}{ STATUS PENJUALAN } \\
\cline { 2 - 3 } & LARIS & $\begin{array}{c}\text { KURANG } \\
\text { LARIS }\end{array}$ \\
\hline Ice Float Mocca & 11 & 19 \\
\hline Ice Float Tropical & 12 & 18 \\
\hline Ice Float Lechy & 12 & 18 \\
\hline Ice Float Orange & 15 & 15 \\
\hline Ice Float Mango & 8 & 22 \\
\hline Sundae Ice Cream & 9 & 21 \\
\hline Pepsi & 15 & 15 \\
\hline Mirinda & 11 & 19 \\
\hline Air Mineral & 18 & 12 \\
\hline
\end{tabular}

Tabel 4. Klasifikasi Berdasarkan Jumlah Terjual

\begin{tabular}{|c|c|c|}
\hline \multirow{2}{*}{$\begin{array}{c}\text { RENTANG } \\
\text { JUMLAH }\end{array}$} & \multicolumn{2}{|c|}{ STATUS PENJUALAN } \\
\cline { 2 - 3 } & LARIS & $\begin{array}{c}\text { KURANG } \\
\text { LARIS }\end{array}$ \\
\hline$<=25$ Pcs & 190 & 334 \\
\hline$>25$ Pcs & 86 & 80 \\
\hline
\end{tabular}

Tabel 5. Klasifikasi Berdasarkan Harga

\begin{tabular}{|c|c|c|}
\hline \multirow{2}{*}{$\begin{array}{c}\text { RENTANG } \\
\text { HARGA }\end{array}$} & \multicolumn{2}{|c|}{ STATUS PENJUALAN } \\
\cline { 2 - 3 } & LARIS & $\begin{array}{c}\text { KURANG } \\
\text { LARIS }\end{array}$ \\
\hline$<=25.000$ & 263 & 397 \\
\hline$>25.000$ & 13 & 17 \\
\hline
\end{tabular}

Tabel 6. Klasifikasi Berdasarkan Menu Makanan

\begin{tabular}{|l|c|c|}
\hline \multirow{2}{*}{$\begin{array}{c}\text { Menu } \\
\text { Makanan }\end{array}$} & \multicolumn{2}{|c|}{ STATUS PENJUALAN } \\
\cline { 2 - 3 } & LARIS & $\begin{array}{c}\text { KURANG } \\
\text { LARIS }\end{array}$ \\
\hline Super Mumer & 13 & 17 \\
\hline Paket Mumer 1 & 11 & 19 \\
\hline Paket Mumer 2 & 11 & 19 \\
\hline Paket Mumer 3 & 12 & 18 \\
\hline Paket Mumer 4 & 13 & 17 \\
\hline Rice Bento & 15 & 15 \\
\hline Original Burger & 6 & 24 \\
\hline
\end{tabular}


ISSN: 2527-5771/EISSN: 2549-7839

http://tunasbangsa.ac.id/ejurnal/index.php/jurasik

\begin{tabular}{|l|c|c|}
\hline \multirow{2}{*}{$\begin{array}{c}\text { Menu } \\
\text { Makanan }\end{array}$} & \multicolumn{2}{|c|}{ STATUS PENJUALAN } \\
\cline { 2 - 3 } & LARIS & $\begin{array}{c}\text { KURANG } \\
\text { LARIS }\end{array}$ \\
\hline Ayam Geprek & 13 & 17 \\
\hline French Fries & 10 & 20 \\
\hline Dada & 14 & 16 \\
\hline Paha Atas & 10 & 20 \\
\hline
\end{tabular}

\begin{tabular}{|l|c|c|}
\hline \multirow{2}{*}{$\begin{array}{c}\text { Menu } \\
\text { Makanan }\end{array}$} & \multicolumn{2}{|c|}{ STATUS PENJUALAN } \\
\cline { 2 - 3 } & LARIS & $\begin{array}{c}\text { KURANG } \\
\text { LARIS }\end{array}$ \\
\hline Sayap & 15 & 15 \\
\hline Paha Bawah & 8 & 22 \\
\hline Nasi Putih & 14 & 16 \\
\hline
\end{tabular}

\subsection{Proses Data Mining}

\subsubsection{Perhitungan Algoritma C4.5}

Perancangan data mining pada penelitian ini menggunakan algoritma C4.5. Proses pada pohon keputusan adalah mengubah bentuk data (table) menjadi model pohon, mengubah model pohon menjadi rule, dan menyederhanakan rule. Kasus yang ada pada Tabel 7 Data Penjualan akan dibuat pohon keputusan untuk menentukan menu makananan yang terjual dengan status penjualannya kurang laris, laris dan sangat laris berdasarkan jenis menu dan nama-nama menu yang ada. Berikut ini adalah penjelasan lebih terperinci mengenai tiap-tiap langkah dalam pembentukan pohon keputusan dengan menggunakan algoritma C4.5:

1. Menghitung : jumlah kasus untuk keputusan Kurang Laris, jumlah kasus untuk keputusan Laris, jumlah kasus untuk keputusan Sangat Laris, menghitung entropy untuk semua kasus, menghitung entropy untuk sub kasus (berdasarkan atribut) dan menghitung gain untuk setiap atribut. Hasil perhitungan untuk node awal dapat dilihat pada table 3.5 di bawah ini.

Tabel 7. Perhitungan Node Awal

\begin{tabular}{|c|c|c|c|c|c|c|c|}
\hline \multirow[b]{2}{*}{ Node } & & & \multirow[b]{2}{*}{$\begin{array}{l}\text { Jumlah } \\
\text { Kasus }\end{array}$} & \multicolumn{2}{|c|}{ Status Penjualan } & \multicolumn{2}{|c|}{ Nilai } \\
\hline & & & & Laris & $\begin{array}{c}\text { Kurang } \\
\text { Laris }\end{array}$ & Entropy & Gain \\
\hline & & & $(\mathrm{S})$ & $(\mathrm{S} 1)$ & (S2) & & \\
\hline \multirow[t]{19}{*}{1} & Total & & 690 & 276 & 414 & 0.970951 & \\
\hline & $\begin{array}{l}\text { Jenis } \\
\text { Menu }\end{array}$ & & & & & & 0.76491 \\
\hline & & Makanan & 420 & 165 & 255 & 0.966619 & \\
\hline & & Minuman & 270 & 111 & 159 & 0.977080 & \\
\hline & $\begin{array}{l}\text { Menu } \\
\text { Makanan }\end{array}$ & & & & & & 1.501991 \\
\hline & & Super Mumer (A) & 30 & 13 & 17 & 0.987138 & \\
\hline & & Paket Mumer 1 (B) & 30 & 11 & 19 & 0.948078 & \\
\hline & & Paket Mumer 2 (C) & 30 & 11 & 19 & 0.948078 & \\
\hline & & Paket Mumer 3 (D) & 30 & 12 & 18 & 0.970951 & \\
\hline & & Paket Mumer 4 (E) & 30 & 13 & 17 & 0.987138 & \\
\hline & & Rice Bento (F) & 30 & 15 & 15 & 1 & \\
\hline & & Original Burger (G) & 30 & 6 & 24 & 0.721928 & \\
\hline & & Ayam Geprek (H) & 30 & 13 & 17 & 0.987138 & \\
\hline & & French Fries (I) & 30 & 10 & 20 & 0.918296 & \\
\hline & & Dada (J) & 30 & 14 & 16 & 0.996792 & \\
\hline & & Paha Atas (K) & 30 & 10 & 20 & 0.918296 & \\
\hline & & Sayap (L) & 30 & 15 & 15 & 1 & \\
\hline & & Paha Bawah (M) & 30 & 8 & 22 & 0.836641 & \\
\hline & & Nasi Putih (N) & 30 & 14 & 16 & 0.996792 & \\
\hline
\end{tabular}


Jurnal Riset Sistem Informasi Dan Teknik Informatika (JURASIK)

Volume (3) Juli 2018, pp 1-13

ISSN: 2527-5771/EISSN: 2549-7839

http://tunasbangsa.ac.id/ejurnal/index.php/jurasik

\begin{tabular}{|c|c|c|c|c|c|c|c|}
\hline \multirow[b]{2}{*}{ Node } & & & \multirow[b]{2}{*}{$\begin{array}{l}\text { Jumlah } \\
\text { Kasus }\end{array}$} & \multicolumn{2}{|c|}{ Status Penjualan } & \multicolumn{2}{|c|}{ Nilai } \\
\hline & & & & Laris & $\begin{array}{c}\text { Kurang } \\
\text { Laris }\end{array}$ & Entropy & Gain \\
\hline & $\begin{array}{l}\text { Menu } \\
\text { Minuman }\end{array}$ & & & & & & 1.21703 \\
\hline & & Ice Float Mocca (A) & 30 & 11 & 19 & 0.948078 & \\
\hline & & Ice Float Tropical (B) & 30 & 12 & 18 & 0.970951 & \\
\hline & & Ice Float Lechy (C) & 30 & 12 & 18 & 0.970951 & \\
\hline & & Ice Float Orange (D) & 30 & 15 & 15 & 1 & \\
\hline & & Ice Float Mango (E) & 30 & 8 & 22 & 0.836641 & \\
\hline & & Sundae Ice Cream (F) & 30 & 9 & 21 & 0.881291 & \\
\hline & & Pepsi (G) & 30 & 15 & 15 & 1 & \\
\hline & & Mirinda $(\mathrm{H})$ & 30 & 11 & 19 & 0.948078 & \\
\hline & & Air Mineral (I) & 30 & 18 & 12 & 0.970951 & \\
\hline & Harga & & & & & & 0.085989 \\
\hline & & $<=25.000(\mathrm{~A})$ & 660 & 263 & 397 & 0.970057 & \\
\hline & & $>25.000(\mathrm{~B})$ & 30 & 13 & 17 & 0.987138 & \\
\hline & $\begin{array}{l}\text { Jumlah } \\
\text { Terjual }\end{array}$ & & & & & & 0.493791 \\
\hline & & $<=25 \operatorname{Pcs}(\mathrm{A})$ & 524 & 190 & 334 & 0.944817 & \\
\hline & & $>25$ Pcs (B) & 166 & 86 & 80 & 0.999057 & \\
\hline
\end{tabular}

2. Pohon keputusan yang terbentuk pada perhitungan manual ditunjukkan pada Gambar 2 berikut:
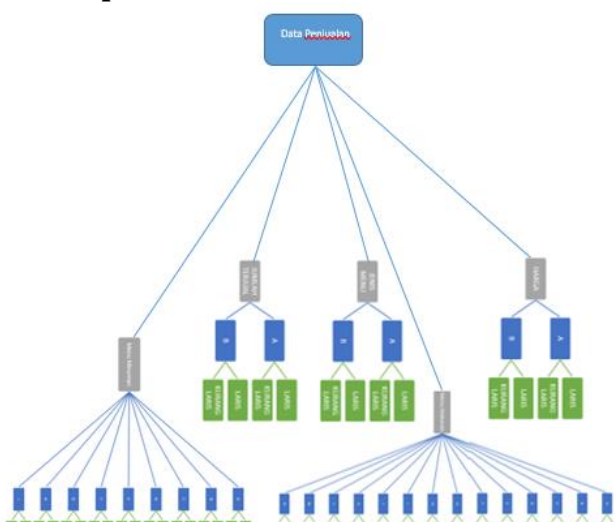

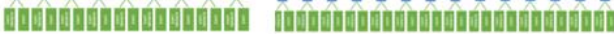

Gambar 2. Pohon Keputusan Perhitungan Manual

Pengujian menggunakan Rapid Miner menghasilkan pohon keputusan seperti di bawah ini :

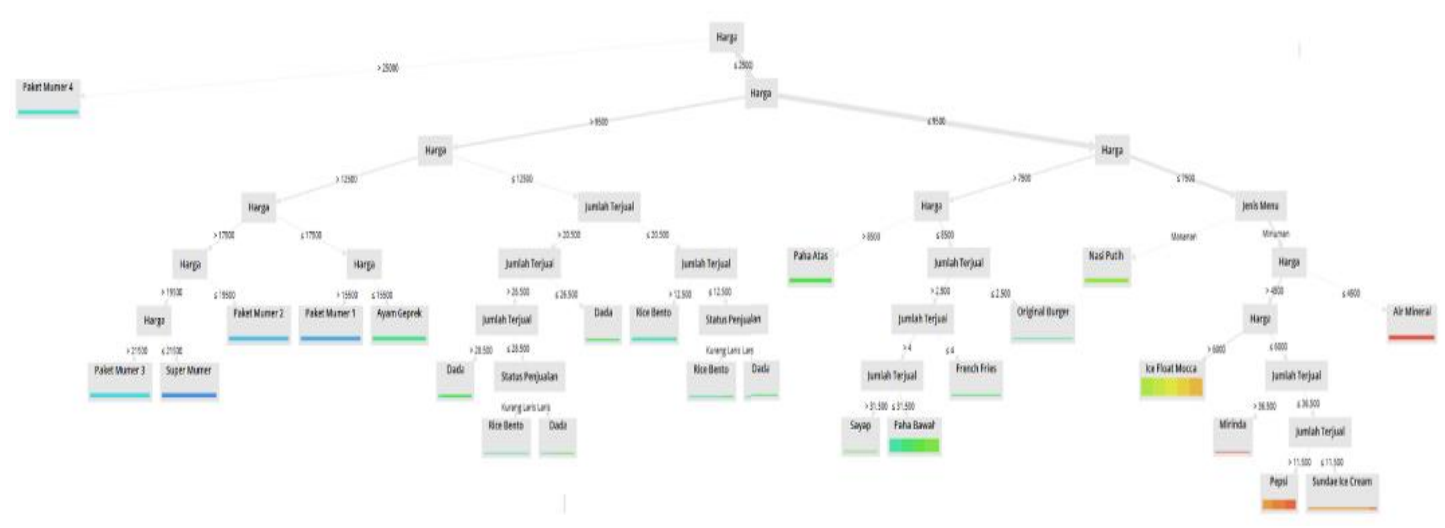

Gambar 3. Pohon Keputusan yang dihasilkan RapidMiner

Mengklasifikasi Data Penjualan Bisnis Gerai Makanan Cepat Saji (Eka Pandu Cynthia) | 11 
Jurnal Riset Sistem Informasi Dan Teknik Informatika (JURASIK)

Volume (3) Juli 2018, pp 1-13

ISSN: 2527-5771/EISSN: 2549-7839

http://tunasbangsa.ac.id/ejurnal/index.php/jurasik

\section{SIMPULAN}

Dari hasil percobaan pencarian pohon hasil keputusan dari data penjualan gerai makanan cepat saji menggunakan algoritma C4.5 dihasilkan nilai entropy dan gain tertinggi yaitu 1,501991 pada atribut-atribut Menu Makanan pada perhitungan manual. Sedangkan menggunakan aplikasi Rapidminer diperoleh hasil pohon keputusan seperti terlihat pada Gambar 3.2. Harga - Jumlah Terjual - Menu Makanan (Rice Bento = Kurang Laris, Dada = Laris) dengan bobot (weight) masing-masing atribut : Harga $(0,738)$, Jenis Menu (0,067), Jumlah Terjual $(0,156)$, Status Penjualan $(0,040)$.

\section{DAFTAR PUSTAKA}

[1]. Arifin, M.F. dan Firianah, Devi., "Penerapan Algoritma Klasifikasi C4.5 dalam Rekomendasi Penerimaan Mitra Penjualan Studi Kasus : PT Atria Artha Persada" IncomTech, Jurnal Telekomunikasi dan Komputer, vol.8, no.2 Halaman 87-102, ISSN : 2085-4811, 2018.

[2]. Ariwibowo, A.S., "Metode Data Mining Untuk Klasifikasi Kesetiaan Pelanggan Terhadap Merek Produk" Seminar Nasional Sistem Informasi Indonesia, Halaman 532-540, 2-4 Desember 2013.

[3]. Azwanti, Nurul., "Analisa Algoritma C4.5 Untuk Memprediksi Penjualan Motor Pada PT. Capella Dinamik Nusantara Cabang Muka Kuning", Jurnal Ilmiah Ilmu Komputer, Informatika Mulawarman Vol 13 No. 1 Halaman 33-38, E-ISSN : 2597-4963 P-ISSN : 1858-4853, Februari 2018.

[4]. Hiriana, Nadiya dan Rasyidan, Muhammad., "Penerapan Metode Decision Tree Algoritma C4.5 untuk Seleksi Calon Penerima Beasiswa Tingkat Universitas” Al Ulum Sains dan Teknologi, Vol. 3 No. 1 Halaman 9-13, November 2017.

[5]. Nugroho, Y.S. dan Alirsyadi, F.Y., "Implementasi Data Mining Sebagai Informasi Strategis Penjualan Batik (Studi Kasus Batik Mahkota Laweyan)" Prosiding SNATIF ke2, Halaman 161-168, ISBN: 978-602-1180-21-1, Universitas Muria Kudus, 2015.

[6]. Pramono, Fajar., et al., "Komparasi Klasifikasi Penentuan Keterlambatan Siswa SMA Datang Upacara Menggunakan Algoritma C4.5" Seminar Nasional Teknologi Informasi dan Komunikasi (Sentika), Halaman 80-86, ISSN : 2089-9815, Yogyakarta 23-24 Maret 2018.

[7]. Rahman, Arif Muhammad., "Algoritma C4.5 Untuk Menentukan Mahasiswa Penerima Beasiswa (Studi Kasus PPS IAIN Raden Intan Bandar Lampung)" Jurnal Tim Darmajaya Vol. 1 No. 2 Halaman 118-128, ISSN : 2442-5567, Oktober 2015.

[8]. Rani, L.N., "Klasifikasi Nasabah Menggunakan Algoritma C4.5 Sebagai Dasar Pemberian Kredit" Jurnal Inovtek Polbeng - Seri Informatika Vol. 1 No. 2 Halaman 126-132, ISSN : 2527-9866, November 2016.

[9]. Rusito dan T.M. Meidy, "Implementasi Metode Decision Tree dan Algoritma C4.5 Untuk Klasifikasi Data Nasabah Bank" Infokam Nomor I Th. XII Halaman 1-12, Maret 2016.

[10]. Susanto, et al., "Penerapan Data Mining Classification Untuk Prediksi Perilaku Pola Pembelian Terhadap Waktu Transaksi Menggunakan Metode Naïve Bayes" Konferensi Nasional Sistem dan Informatika STMIK STIKOM, Halaman 313-318, Bali, 9-10 Oktober 2015.

[11]. Tyas, A.F. et al., "Klasifikasi Data Dengan Menggunakan Algoritma C4.5 dan TAN" Tugas Akhir Program Studi S1 Teknik Informatika, Fakultas Teknik Informatika, Universitas Telkom, Halaman 15-61, 2010. 
Jurnal Riset Sistem Informasi Dan Teknik Informatika (JURASIK)

Volume (3) Juli 2018, pp 1-13

ISSN: 2527-5771/EISSN: 2549-7839

http://tunasbangsa.ac.id/ejurnal/index.php/jurasik

[12]. Winata, A.D., "Analisis dan Prediksi Penjualan Produk Terlaris Distro RootShoes Dengan Aplikasi Android" Artikel Publikasi Universitas Muhammadiyah Surakarta, 2017. 